\title{
A NEW SPECIES AND FIRST RECORD OF THE GENUS SOLENOCENTRUM (ORCHIDACEAE: CRANICHIDINAE) FROM PERU
}

\author{
Alexander Damián ${ }^{1,5}$, Gerardo A. Salazar ${ }^{2}$, Nicole Mitidieri $^{3} \&$ Saul Altamirano $^{4}$ \\ ${ }^{1}$ Carrera de Ingeniería Agroforestal. Universidad Científica del Sur, Lima, Peru \\ ${ }^{2}$ Departamento de Botánica, Instituto de Biología, Universidad Nacional Autónoma de México, \\ Apartado Postal 70-367, 04510 Mexico City, Mexico \\ ${ }^{3}$ Food and Agriculture Organization of the United Nations (FAO-Peru), Calle Manuel Almenara 328, \\ La Aurora, Miraflores, Lima, Peru \\ ${ }^{4}$ Herbario Nacional Forestal Martín Cárdenas (BOLV), Cochabamba, Bolivia \\ ${ }^{5}$ Author for correspondence: ldamian@cientifica.edu.pe
}

\begin{abstract}
Aвstract. Solenocentrum oblongum from southern Peru is described and illustrated, representing the first record of this genus for the country. It is similar to Bolivian S. lueri, but can be distinguished by its oblong, sub-pandurate labellum (vs. triangular to sagittate) with rounded base (vs. sagittate), glabrous margins (vs. densely ciliate) and slender oblong calli (vs. broadly ovate). Line drawings of labellum outlines and an identification key to the four accepted species of Solenocentrum are provided.

RESUMEN. Se describe e ilustra Solenocentrum oblongum del sur peruano, representando el primer registro de este género para el país. Es similar a la especie boliviana $S$. lueri, pero se distingue por su labelo oblongo, subpandurado (vs. triangular a sagitado) con base redondeada (vs. sagitada), márgenes glabros (vs. densamente ciliados) y callos oblongos, delgados (vs. ampliamente ovados). Se proporcionan dibujos en línea del labelo, y una clave de identificación de las cuatro especies aceptadas de Solenocentrum.
\end{abstract}

Key Words / Palabras clave: Andes, Bolivia, Cusco, Pseudocentrum, Solenocentrum lueri

Introduction. The genus Solenocentrum Schltr. encompasses four nominal species found in Costa Rica, Panamá, Colombia, Ecuador, Perú and Bolivia (Govaerts et al. 2020, G. A. Salazar, unpubl. data), and is one of the less-known taxa within subtribe Cranichidinae. Species of this genus are terrestrial or occasionally epiphytic ( $S$. costaricense Schltr.) in premontane and montane cloud forests at 1400-2600 $\mathrm{m}$ in elevation. The genus is characterized by its rosette of 3-5 long-petiolate leaves with elliptic, slightly asymmetrical, acuminate blades; non-resupinate flowers; free sepals; asymmetric, two-lobed petals; and labellum provided at base with a long, slightly clavate spur (Schlechter 1911, Cribb 2003). Both the petals and the labellum are attached from about the middle to near the apex of the column, which is clavate, with pointed rostellum and four soft pollinia in two unequal pairs (Cribb 2003, Dodson 2004).

Solenocentrum is similar in overall vegetative and floral morphology to Baskervilla Lindl., Ponthieva R.Br. and Pseudocentrum Lindl., but both Baskervilla and Ponthieva are easily told apart by their concave labellum lacking a distinct spur (Cribb 2003, Salazar et al. 2009). Solenocentrum and Pseudocentrum, on the other hand, are unique among the Cranichidinae in the possession of a tubular labellum spur, which in Solenocentrum is straight, slightly expanded at its apex (i.e. clavate) and fully exposed, whereas in Pseudocentrum the spur is strongly inflexed near the apex and enclosed by the connate lateral sepals (Fig. $1 \mathrm{~A}-\mathrm{B})$.

It is worth noting that, as noted by Dressler (1998) and Dodson (2004), Solenocentrum asplundii (Garay) Garay lacks a tubular spur and its overall morphology fits in Cranichis Sw., the genus in which it was originally described (Fig. 1C-D). Such placement is in agreement with the results of a phylogenetic analysis of nuclear (ITS) and plastid (matK, trnL-trnF) DNA sequences (G.A. Salazar, unpubl. data). Hence, in the following we exclude this species from discussion on species of Solenocentrum.

The genus Solenocentrum has not been recorded 

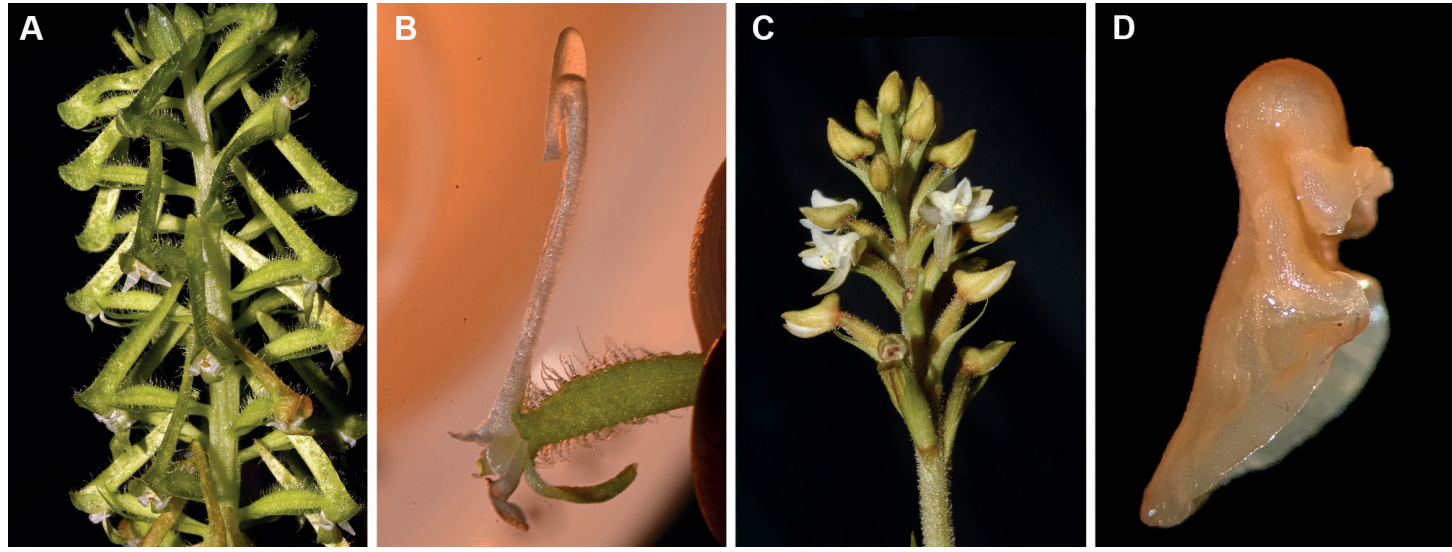

Figure 1. A-B. Pseudocentrum purdii (Ecuador, Salazar 10023). A. Close up of inflorescence. B. Flower from side with the sepals and petals excised to show the labellum with the tubular spur strongly inflexed near the apex; notice the accumulation of fluid (nectar). C-D. Cranichis ("Solenocentrum") asplundii (Ecuador, Salazar et al. 10064). C. Inflorescence. D. Labellum from side showing the prominently saccate base. Photos by Gerardo A. Salazar.

previously in Perú (Schweinfurth 1958, Brako \& Zarucchi 1993, Ulloa Ulloa et al. 2004, 2017, Zelenko \& Bermudez 2009, Goicochea et al. 2019). However, while conducting a revision of specimens of the genus Baskervilla as part of a research stay funded by a fellowship from the Missouri Botanical Garden, the senior author found a Peruvian specimen labeled as "Baskervilla" but lacking the characteristics of this genus, showing instead a distinct labellum spur. After detailed comparison of its floral traits with the literature and comparison with other specimens, it was clear that it belonged to Solenocentrum but it did not match any known species. In the following, we describe the Peruvian entity as a new species, provide a detailed drawing and color photographs and compare it with all known species of Solenocentrum.

Materials and methods. Morphological observations and measurements were carried out on pressed specimens and flowers from herbarium specimens softened by immersion in hot soapy water. Photographs were taken with a digital camera (Nikon D810, Nikon Corporation, Tokyo, Japan) provided with a $105 \mathrm{~mm}$ AF Micro Nikkor lens (Nikon). The specimen of the new species was compared with other specimens housed in the herbaria MO, HOXA, USM and CUZ (acronyms according to Thiers 2019). Digital images of additional specimens held at SEL and S were also consulted through the JSTOR portal (https://plants.jstor.org/). Line drawings of selected specimens examined were made using a Euromex SB-1903 stereomicroscope and processed with Adobe Photoshop CC v. 14.0.

\section{TAXONOMIC TREATMENT}

Solenocentrum oblongum Damián \& Mitidieri, sp. nov.

TYPE: PERU. Cusco, Prov. La Convención, Dto. Vilcabamba, Oyara, Sarahuasi, bosque primario humedo, $13^{\circ} 01^{\prime} 18^{\prime \prime} \mathrm{S} 072^{\circ} 49^{\prime} 13^{\prime \prime} \mathrm{W}, 2200-2500 \mathrm{~m}$, hierba $30 \mathrm{~cm}$, flores verdes, columna verde amarillenta, 23 Feb 2007, L. Valenzuela, E. Suclli et al. 8947 (holotype MO!, isotype CUZ!). Fig. 2, 4A, 5D.

Diagnosis: Similar to Solenocentrum lueri Dodson \& R.Vásquez, differing in its oblong, sub-pandurate labellum (vs. triangular to sagittate) with rounded base (vs. sagittate), glabrous margins (vs. densely ciliate) and slender oblong calli (vs. broadly ovate).

Terrestrial, acaulescent herbs, 22-30 cm tall including the inflorescence. Roots fasciculate, terete, fleshy, pilose, $0.2-0.3 \mathrm{~cm}$ in diameter. Leaves $3-8$, forming a basal rosette, with ascending, basally sheathing petioles $4-8 \mathrm{~cm}$ long; blades horizontal, elliptic, $7.0-11.5 \times 2.6-4.4 \mathrm{~cm}$, basally symmetrical and broadly cuneate, apex acuminate, margins entire. Inflorescence racemose, erect, arising from the center of the rosette of leaves, $10-17 \mathrm{~cm}$ long; peduncle terete, green, $8-10 \mathrm{~cm}$, with a basal ovate acuminate glabrous bract, $4-8 \mathrm{~cm}$ long; above with 3 more bracts 


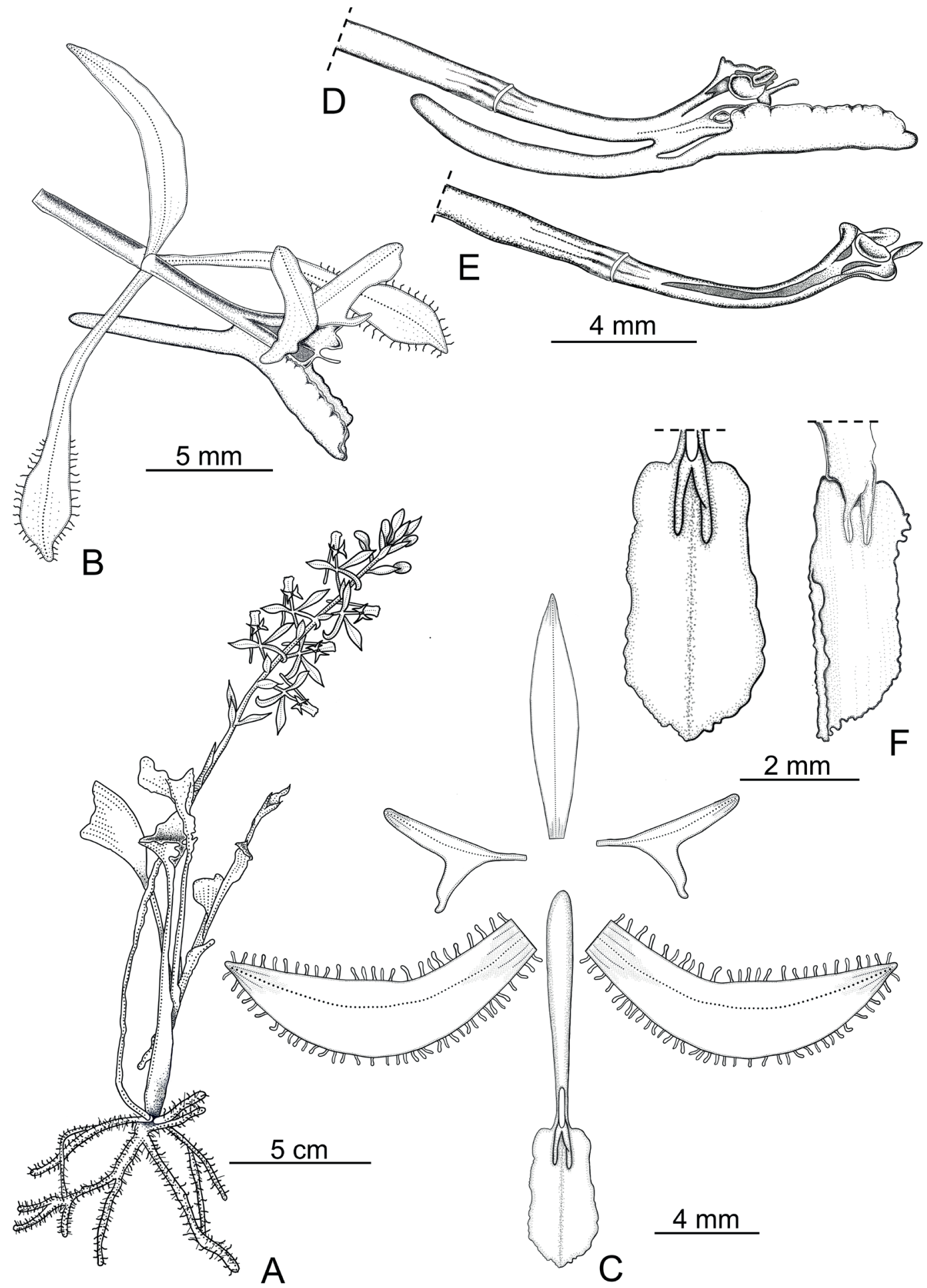

Figure 2. Solenocentrum oblongum Damián \& Mitidieri. A. Habit. B. Flower. C. Dissected Flower. D. Column and labellum, lateral view. E. Column lateral view. F. Labellum. Drawn from the holotype by Nicole Mitidieri. 


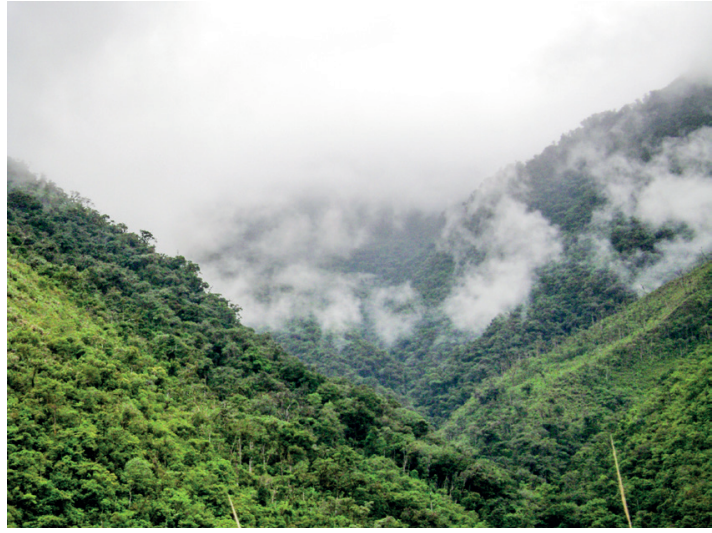

FIgURE 3. Landscape at Oyara-Sarahuasi (Vilcabamba, Cusco), where the holotype of Solenocentrum oblongum was collected. Photograph by Luis Valenzuela.

just below the flowers, $1.3-1.4 \times 0.3 \mathrm{~cm}$. Floral bracts lanceolate, acuminate, glabrous, 3-veined, 1.0-1.4 $\times 0.1-0.3 \mathrm{~cm}$. Flowers 6-30, non-resupinate; sepals greenish, petals white, labellum greenish with white calli. Ovary greenish, terete, glabrous, $0.8-0.9 \mathrm{~cm}$ long. Dorsal sepal erect, convex, slightly recurved at apex, glabrous, narrowly oblanceolate, acute, margins entire, 1-veined, $0.9 \times 0.12 \mathrm{~cm}$. Lateral sepals free, spreading, margins densely ciliate and dorsally sparsely pubescent, falcate, acute, 3-veined, midvein conspicuous, lateral veins obscure, $1.1 \times 0.2 \mathrm{~cm}$. Petals attached near the apex of the column, glabrous, 1-veined, clawed, two-lobed above the claw, 0.6 total length, $0.3 \mathrm{~cm}$ wide near the middle; upper lobe lanceolate, rounded, lower lobe obliquely triangular, subacute. Labellum united to the column just under its apex, slightly recurved, oblong, obscurely pandurate, conduplicate, glabrous, 3-veined, with a thickened midvein, obtuse, margins irregularly undulate, $0.47 \times$ $0.24 \mathrm{~cm}$, provided at base with a callus formed by two terete lobes forming an inverted "V", $0.17 \mathrm{~cm}$ long; spur clavate, minutely pubescent inside, $0.84 \mathrm{~cm}$ long. Column clavate, glabrous, lacking a foot, $0.85 \mathrm{~cm}$ long, provided at each side of the apex with a short triangular wing; anther ovoid, $1.5 \mathrm{~mm}$ long; rostellum elongate, acute, $0.8 \mathrm{~mm}$ long; stigma suborbicular, slightly convex. Pollinarium and fruits not seen.

Distribution And Ecology: Solenocentrum oblongum is known only from the locality of Oyara-Sarahuasi (Vilcabamba, Cusco) (Fig. 3). The species was found growing as a terrestrial in a low montane forest with abundant loose limestone rock and a superficial layer of black soil, between 2200 and $2500 \mathrm{~m}$ in elevation. The surrounding vegetation was mainly composed by Abatia spicata (Turcz.) Sleumer (Salicaceae), Clethra revoluta (Ruiz \& Pav.) Spreng., Hieronyma oblonga (Tul.) Müll.Arg. (Phyllanthaceae), Saurauia biserrata (Ruiz \& Pav.) Spreng. (Actinidiaceae), and tree ferns of the genus Dicksonia L'Hér. (Dicksoniaceae).

Eтymology: The epithet refers to the oblong labellum, which easy differentiates this species from its congeners (Fig. 5).

Solenocentrum oblongum is most similar to $S$. lueri (Fig 4B, 5C), so far known only from the montane forest of Carrasco, Bolivia. Both species share similar floral traits, such as an elongate column and ciliate, oblong lateral sepals, but are easily distinguished from each other by their different labellum morphology: triangular to sagittate in S. lueri and oblong, subpandurate in S. oblongum. There is some variation in labellum morphology in S. lueri, documented by one of us (SA) in a recent fieldwork close to the type locality. In such recent collection (Saúl Altamirano 5164, BOLV), the labellum is not as definitely triangular as described by Dodson and Vásquez (1989), being instead sagittate with broadly obtuse apex and ciliate margins (contrary to the narrowly obtuse and entire margins shown in the protologue).

Both S. oblongum, and S. lueri grow in cloud forest of the eastern slope of the Andes at 2200-2600 m in elevation. The Bolivian and Peruvian populations of these species are separated from each other by about $950 \mathrm{~km}$ in a straight line, and the presence of this genus in intermediate areas like Puno in Peru and $\mathrm{La} \mathrm{Paz}$ in Bolivia is highly probable. The two Central American species ( $S$. costaricense and $S$. maasii) are easily distinguished by their wider lobulate lateral sepals, sub-triangular petals and short column (3-4 mm long) (Fig. 5 A-B). In contrast, S. oblongum bears oblong non-lobulate lateral sepals, two-lobed petals and long column $(8.5 \mathrm{~mm})$.

Additional specimens examined: Solenocentrum lueri Dodson \& R.Vásquez. Bolivia: Prov. Carrasco, cloud forest below Monte Puncu along Río Lope Mendoza, 2400-2600 m, 1 Feb. 1981, C. Luer, J. Luer \& et 


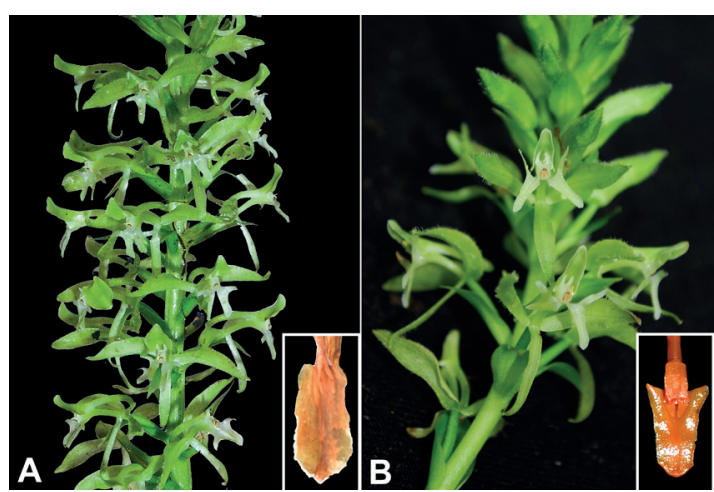

FIgURE 4. Inflorescence and spread out labellum of Solenocentrum oblongum Damián \& Mitidieri (A) and Solenocentrum lueri Dodson \& R.Vásquez (B). Photographs by Luis Valenzuela (A) and Saul Altamirano (B).

al. 5829 (SEL-photo); Departamento Cochabamba, Prov. Carrasco, Sehuencas, bosque húmedo montano, 30 Jan 2019, 17.29.13 65.16.29, 2351 m, Saúl Altamirano 5164 (BOLV). Solenocentrum costaricense Schltr. Costa Rica: Prov. Puntarenas, Cordillera de Talamanca, forested slopes along the Río Buru, upper slopes of Cerro Buru, ca. $901 \mathrm{~N}, 82,52$ W, 1900 m, 19 Aug. 1983, G. Davidse, L.D. Gomez \& et al. 23757 (MO); Prov. Cartago, Río Amigos, 8
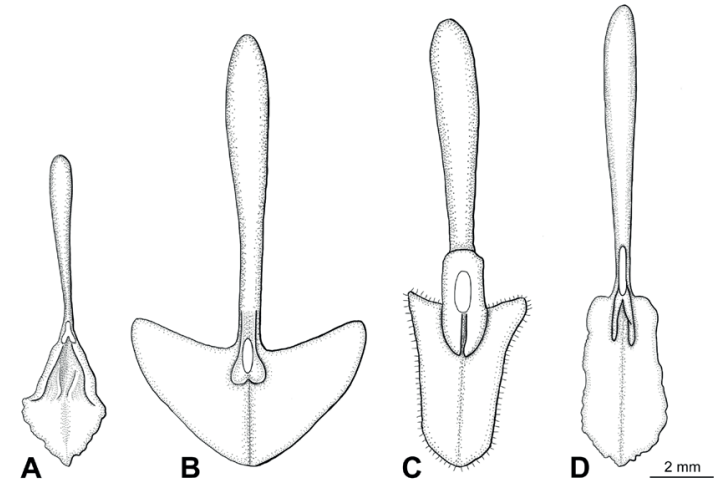

FIGURE 5. Labellum comparison of known species of Solenocentrum. A. S. maasii [holotype Maas 1479 (MO)]. B. S. costaricense [Soto $78(\mathrm{MO})]$. C. S. lueri [Altamirano 5164 (BOLV)]. D. S. oblongum [holotype Valenzuela et al. 8947 (MO)]. Illustration by Nicole Mitidieri.

km S. of Tapantí, 1600 m, 17 Oct. 1971, Roy W. Lent 2200 (MO); Puntarenas, Canton de Puntarenas, R.B. Bosque Eterno de los Niños. Cuencas del Lagarto y Guacimal. Monteverde, Sendero Chomogo y el Roble. $10^{\circ} 18^{\prime} 00^{\prime N}$ 8448'00”W, 1600 m, 19 Oct. 1997, Armando Soto 78 (MO). Solenocentrum maasii Dressler. Costa Rica: Prov. Puntarenas, Las Alturas and vicinity forest, $1800 \mathrm{~m}, 26 \mathrm{Aug}$ 1974, P.J.M. Maas \& B. Mc. Alpin 1479 (MO).

Key to THE SPECIES OF SOLENOCENTRUM

1 Lateral sepals conspicuously lobulate; column $<5 \mathrm{~mm}$ long, less than one half as long as the labellum spur; restricted to Central America (Costa Rica and Panama)

2. Sepals up to $13 \times 7 \mathrm{~mm}$; labellum lunate with conspicuous basal lobes; ovary glandular-pilose

S. costaricense

2a. Sepals up to $7 \times 5 \mathrm{~mm}$; labellum ovate, devoid of lobes; ovary glabrous S. maasii

1a. Lateral sepals non-lobulate; column $8-10 \mathrm{~mm}$; restricted to the Andes (Peru and Bolivia) 3

3. Labellum triangular to sagittate, margins ciliate S. lueri

3a. Labellum oblong, sub-pandurate, margins glabrous

S. oblongum

ACKNOWLEDGMENTS. The authors are very grateful to the curators of MO, HOXA, USM, CUZ and MO for their kindness in allowing the revision of their collections. Our greatest gratitude to Shirley Graham and Missouri Botanical Garden who awarded the first author (AD) a fellowship to study their unique collection. A special thanks to Luis Valenzuela (HOXA) for sharing in situ photographs of S. oblongum and details about its ecology.

\section{LITERATURE CITED}

Brako, L. \& Zarucchi, J. (1993). Catalogue of the Flowering Plants and Gymnosperms of Peru. Monographs in Systematic Botany of the Missouri Botanical Garden, 45, 414-425.

Cribb, P. (2003). Solenocentrum. In: A. M. Pridgeon, P. J. Cribb, M. W. Chase \& F. N. Rasmussen (Eds.), Genera Orchidacearum, volume 3, Orchidoideae (part 2), Vanilloideae (pp. 55, 57-59). Oxford: Oxford University Press. 
Dodson, C. H. (2004). Native Ecuadorian Orchids, Volume $V$, Rodriguezia - Zygosepalum. Sarasota: Dodson Publishing.

Dodson, C. H. \& Vásquez, R. (1989). Icones Plantarum Tropicarum, Series 2, Fascicle 3: Orchids of Bolivia. St. Louis: Missouri Botanical Garden.

Dressler, R. L. (1998). Orchids of Mesoamerica 2, Cranichidinae. Boletín del Instituto de Botánica, Universidad de Guadalajara, 5, 69-85.

Goicochea, A., Gutiérrez, A. D., Ruiz, A. \& Salas, M. (2019). Orquídeas de Perú: relación de especies y sus sinónimos. Lima: Corporación $\mathrm{G} \& \mathrm{G}$.

Govaerts, R., Bernet, P., Kratochvil, K., Gerlach, G., Carr, G., Alrich, P., Pridgeon, A. M., Pfahl, J., Campacci, M. A., Holland Baptista, D., Tigges, H., Shaw, J., Cribb, P., George, A., Kreuz, K. \& Wood, J. (2020). World checklist of Orchidaceae. Kew: Royal Botanic Gardens. Retrieved from http://apps.kew.org/wcsp/ [accessed 12 January 2020]

Salazar, G. A., Cabrera, L. I., Madriñán, S. \& Chase, M. W. (2009). Phylogenetic relationships of Cranichidinae and Prescottiinae (Orchidaceae, Cranichideae) inferred from plastid and nuclear DNA sequences. Annals of Botany, 104, 403-416. doi: https://doi.org/10.1093/ $\mathrm{aob} / \mathrm{mcn} 257$
Schlechter, R. (1911). XXXI. Orchidaceae novae et criticae. Repertorium Specierum Novarum Regni Vegetabilis, 9(205-207), 161-166.

Schweinfurth, C. (1958). Orchids of Peru, part 1. Fieldiana, Botany, 30, 1-260.

Thiers, B. (2019). Index Herbariorum. A global directory of public herbaria and associated staff. New York Botanical Garden's Virtual Herbarium. Retrieved from http://sweetgum.nybg.org /science/ih/ [accessed 1 January 2020].

Ulloa Ulloa, C., Zarucchi, J. L. \& León, B. (2004). Diez años de adiciones a la flora del Perú: 1993-2003. Arnaldoa (Edic. Esp. Noviembre 2004), 1-242.

Ulloa Ulloa, C. U., Acevedo-Rodríguez, P., Beck, S., Belgrano, M. J., Bernal, R., Berry, P. E., Brako, L., Celis, M., Davidse, G., Forzza, R. C., Gradstein, S. R., Hokche, O., León, B., León-Yánez, S., Magill, R. E., Neill, D. A., Nee, M., Raven, P. H., Stimmel, H., Strong, M. T., Villaseñor, J. L., Zarucchi, J. L., Zuloaga, F. O. \& Jørgensen, P. M. (2017). An integrated assessment of the vascular plant species of the Americas. Science 358, 1614-1617. doi: 10.1126/science.aao0398

Zelenko, H. \& Bermudez, P. (2009). Orchids, species of Peru. Quito: ZAI Publications. 